Estudios de Economía Aplicada Vol. $36-2 \quad 2018$ Págs. 489-514

\title{
The Use of Fair Value Measurement in Financial Reporting: A Literature Review
}

\author{
CONSTANCIO ZAMORA-RAMÍREZ ${ }^{\text {a }}$, JOSÉ MORALES-DÍAZ ${ }^{\text {b }}$ \\ a Universidad de Sevilla, Facultad de Ciencias Económicas y Empresariales, Calle Ramón y Cajal 1, \\ 41018 Sevilla, España.E-mail: constancio@us.es \\ ${ }^{b}$ Instituto de Estudios Bursátiles (IEB), Calle Alfonso XI, 6, 28014 Madrid, España. E-mail: \\ jose.morales@claustro-ieb.es
}

\begin{abstract}
Over the last forty years ago, fair value has increasingly been used in IASB and FASB accounting standards. In this sense, there has been significant debate with regard to the relevance and reliability of fair value as a measurement basis. In principle, IASB and FASB conceptual frameworks are based on the Utility Paradigm, and fair value should be used if it offers relevant information for investors. In this article we analyse previous fair value literature, focusing on financial instruments and value relevance. We structure the literature according to the different lines of research, and we describe the findings for each. The authors find that fair value is the model that better reflects risk management activities. Fair value information is generally relevant to investors. The evidence is higher in Level 1 and Level 2 fair value measurements.
\end{abstract}

Keywords: Fair Value Accounting, Fair Value Relevance, Financial Instruments, IFRS, FASB.

\section{La Utilización del Valor Razonable en la Contabilidad: Revisión de la Literatura}

\begin{abstract}
RESUMEN
Desde hace unos cuarenta años, el valor razonable se ha venido utilizando cada vez más en las normas emitidas por el IASB y por el FASB. En este sentido, ha existido un gran debate con relación a la relevancia y a la fiabilidad del valor razonable como método de valoración. En principio, los marcos conceptuales del IASB y del FASB se basan en el Paradigma de la Utilidad, y el valor razonable debería aplicarse si ofrece información relevante a los inversores. En el presente artículo revisamos las investigaciones previas en torno al valor razonable (centrándonos en el área de instrumentos financieros y la relevancia del valor razonable). Hemos clasificado los artículos en líneas de investigación y hemos analizado principales conclusiones obtenidas en cada línea. Los autores concluyen que el valor razonable es el modelo que mejor refleja las actividades de gestión de riesgo. La información que ofrece el valor razonable es generalmente relevante para los inversores. La evidencia es mayor en los valores razonables clasificados en los Niveles 1 y 2.

Palabras clave: Contabilidad del valor razonable, relevancia del valor razonable, instrumentos financieros, NIIF, FASB.
\end{abstract}

JEL Classification: M41, G12

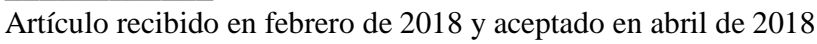

Artículo disponible en versión electrónica en la página www.revista-eea.net, ref. ə-36211

ISSN 1697-5731 (online) - ISSN 1133-3197 (print) 


\section{INTRODUCTION}

Fair value is currently one of the most widely used measurement methodologies in IFRS ${ }^{1}$ accounting standards, as well as in FASB ${ }^{2}$ standards. It is applied (on a voluntary or compulsory basis) for the initial or subsequent measurement of many kinds of assets and liabilities, and it is also used as the basis for several financial statement disclosures. In the IFRS context, it is included in standards such as IFRS 9 (Financial Instruments), IFRS 2 (Share Based Payments), IAS $^{3} 16$ (Property Plant and Equipment), IAS 36 (Impairment of Assets) IAS 40 (Investment Property), IFRS 3 (Business Combinations), etc. ${ }^{4}$

By way of example, as regards financial instruments within the scope of IFRS 9, all financial assets and liabilities should initially be measured at their fair value $^{5}$. Subsequently, all financial assets should be measured at their fair value except for those that meet two requirements: their cash flows are solely payments of principal and interest over the remaining nominal amount, and they are managed in order to collect contractual cash flows. Financial liabilities are subsequently measured at fair value if they are trading liabilities or if they are voluntarily included in the fair value option. Moreover, with regard to all financial instruments not subsequently measured at their fair value, the entity should disclose their fair value in the notes to the financial statements (as required by paragraph 25 of IFRS 7).

A further example is that all investment property items within the scope of IAS 40 are subsequently measured at their fair value unless the entity chooses the cost model (and in this case fair value should be disclosed) (see paragraph 30 of IAS 40).

This measurement methodology (fair value), is not new in accounting (Morales, 2017). Since as early as the nineteenth century, the scientific community and companies have been analysing, even applying, fair value on financial instruments and other elements in the statement of financial position. Since then, the debate regarding the expansion of the use of fair value as a measurement basis has gone through many stages, depending on the specific situation, the international context, the influence of different economic agents,

1 International Financial Reporting Standards (IFRS) issued by the International Accounting Standards Board (IASB).

${ }^{2}$ Financial Accounting Standards Board (FASB), the body that issues US Generally Accepted Accounting Standards (US GAAP).

${ }^{3}$ International Accounting Standard (IAS).

${ }^{4}$ For an analysis of the use of fair value through the different IFRS standards, see Cairns (2006). For a history of the use of fair value by the IASB in the different standards, see Shanklin et al. (2011).

${ }^{5}$ Except for trade receivables that do not have a significant financing component (see IFRS 9 paragraphs 5.1.1 and 5.1.3). 
etc. (Hodder et al., 2006, 2014; Landsman, 2007; Laux and Leuz, 2009; Marra, 2016). For Herz (2013, p.156) - a former chairman of the FASB - one of the oldest, longest, most controversial and, in his view, still to be adequately resolved accounting issues concerns how financial assets and liabilities should be valued. Some authors even pinpoint the origin of the debate to several centuries earlier: according to Emerson et al. (2010, p.77), accountants have been concerned with issues related to the valuation of financial statement components since Pacioli coded double-entry accounting in 1494.

Although fair value is not new in accounting, its use has increased to a greater extent over the last 40 years, following a very long period during which historical cost / acquisition cost prevailed as the main measurement basis. In the late 1970s, the FASB started to require the inclusion of fair value disclosures in the notes to financial statements and since then, both the FASB and the IASB (known together as "the boards") started to use fair value for the measurement of different assets and liabilities. In 2008, the boards even raised the possibility - as previously proposed by the Joint Working Group (JWG, 2000) ${ }^{6}$ - of applying fair value to the subsequent measurement of all financial instruments (IASB, 2008). This still has not happened due to the pressure of many voices against the socalled Full Fair Value Model (FFV). ${ }^{78}$

Accompanying the increase in fair value accounting over the last 40 years, there have been several academic debates regarding the benefits and the consequences of fair value, mainly focused on financial instruments). For example, when the FASB started to require fair value disclosures during the 1970 s and 1980s, many authors analysed the relevance of these disclosures to users of financial statements (mainly investors). In fact, the increase in the use of fair value is generally justified in relation to the Utility Paradigm ${ }^{9}$, which constitutes the basis of FASB and IASB Conceptual Framework. If the information is relevant, it should be included not only in the notes, but also in the statement of financial position. In our opinion, this research line is still under development, due in the main to two different factors:

1) The Full Fair Value Model is still not being applied.

\footnotetext{
${ }^{6}$ The Joint Working Group (JWG) was a working group created by issuers of accounting standards and professional organizations from Australia, Canada, France, Germany, Japan, New Zealand, five Nordic countries, the United Kingdom, the United States and the former IASC (International Accounting Standards Committee). Its objective was to develop a proposal for a financial instruments standards accounting based on fair value principles.

${ }^{7}$ As can be seen in the response letters to the Discussion Paper: Reducing complexity in reporting financial instruments issued in 2008 by the IASB and the FASB.

${ }^{8}$ Under this model, all financial instruments would be measured at fair value on the balance sheet (FFV for financial instruments). Generalising, under a general FFV model, all elements would be measured at fair value on the balance sheet.
}

${ }^{9}$ See Tua (1990), Cañibano et al. (1999), and Nevado and López (2002). 
2) Fair value disclosure requirements are increasing and more information is available for conducting research. For example, IFRS 13 (applicable since 2013) required the classification in fair value Levels 1,2 and $3^{10}$ of not only financial instruments measured at fair value on the balance sheet (already required by IFRS 7), but also of financial instruments about which fair value is disclosed in the notes to the financial statements.

In 2011 the IASB issued a new standard (IFRS 13), whose objectives were to define fair value, to set out (in a single IFRS) a framework for measuring fair value, and to require fair value disclosures. The FASB had previously issued a very similar standard in 2006 (SFAS $^{11} 157$, currently ASC ${ }^{12}$ 820). Many authors analysed the impact of these standards in financial information.

There are very few studies that carry out a comprehensive review of fair value literature, analysing both the different research lines and describing the main findings of the authors. Mention should be made of Fortin (2005), Bonaci and Tudor (2011), Menicucci and Paolucci (2016), Bona et al. (2017), and Sapkauskiene and Orlovskij (2017). However, they generally focus just on one aspect (on one research line), and do not carry out a comprehensive review of the literature. For example, Sapkauskiene and Orlovskij (2017) basically focus on relevance of Level 3 fair values.

The aim of this paper is to classify fair value literature according to lines of research, and analyse the main findings of the authors of said lines of research. We will concentrate mainly on the following:

- Financial instruments.

- Fair value relevance area.

- IFRS and USGAAP accounting regulation framework.

There are more fair value research lines than those described in Section 3, and these are not covered in this paper. For example, in the years 2008-2013, authors analysed the role of fair value in the recent financial crisis. They analysed whether the use of fair value accounting (especially in financial instruments) had a role in magnifying of attenuateing the crisis. Nevertheless, as previously stated, we will focus on aspects of value relevance, i.e. the usefulness of the information that fair value offers to stakeholders.

The rest of the paper is organised as follows: Section 2 describes the basic financial instruments accounting models; this description is relevant since these models will be referred to throughout the paper. Section 3 contains the research methodology; in this section we describe the lines of research. Sections 4 to 9

\footnotetext{
${ }^{10}$ See level descriptions and further details in Section 6.2.

${ }^{11}$ Statement of Financial Accounting Standards (SFAS).

${ }^{12}$ Accounting Standards Codification (ASC). Since 2009, US GAAP standards were superseded by a general code structured in 90 topics.
} 
are dedicated to a review of the main papers and findings of each fair value line of research. Finally, Section 10 includes a summary of the main conclusions of each line reviewed.

\section{FINANCIAL INSTRUMENTS ACCOUNTING MODELS}

If we analyse accounting history since the nineteenth century, and if we also look at the different geographical contexts, we could reference many different models which are applicable to financial instruments accounting. However, if we focus solely on the last 70 years, we can distinguish three major approaches: the Cost Model; the Mixed Model; and the FFV Model.

The Cost Model would be the model in which all financial instruments are measured, generally speaking at their acquisition cost, and in which only the "realised" results are recognised. It is the model that historically has been used almost all over the world from the beginning of what we could call modern accounting normalization (following the Great Depression) until the appearance of mixed models in the 1990s. It is a model guided by the classic concepts of cost allocation, prudence and the recognition of realised results (except in the case of impairment provisions).

Although based on acquisition cost as a general principle, fair value is also used in some types of transactions and measurements (see Cairns, 2006). As pointed out by Shanklin et al. (2011, p.23), the historical cost model for financial accounting has been the general norm in the US and in many parts of the world for several years.

In the Mixed Model, which has multiple variants, both acquisition cost and fair value are applied for subsequent financial instruments measurement. The accounting standards establish several categories to which all financial instruments should be allocated. Depending on the category, subsequent measurement is acquisition cost/amortised cost or fair value. The current models included in the IASB and FASB regulations are mixed models.

The FFV Model has not yet been applied in practice (at least not in the major world economies), but it has been formulated theoretically (JWG, 2000), and it has also been established in some documents as a final objective by the IASB and the FASB. In this FFV Model, all financial instruments are initially and subsequently measured at fair value (with changes recorded in profit or loss).

The following table shows the general characteristics of each model, as well as the use of fair value as a method for subsequent measurement for each. It should be noted that, as previously stated, each model could have multiple variants and details. 
Table 1

Financial Instruments Accounting Models

\begin{tabular}{|c|c|c|c|}
\hline Model & Brief description & Fair value & $\begin{array}{l}\text { Counterpart of fair } \\
\text { value/recognition of } \\
\text { unrealised results }\end{array}$ \\
\hline $\begin{array}{c}\text { Cost Model } \\
\text { (Traditional Model) }\end{array}$ & $\begin{array}{l}\text { The general rule is that all financial } \\
\text { instruments are initially and } \\
\text { subsequently measured at their } \\
\text { acquisition cost (except in the case } \\
\text { of certain impairments in financial } \\
\text { assets). }\end{array}$ & $\begin{array}{c}\text { In general it is not applied except for cases } \\
\text { such as impairments or losses in } \\
\text { investments. }\end{array}$ & $\begin{array}{l}\text { Impairments are recognised } \\
\text { though profit or loss. } \\
\text { Generally, only realised results } \\
\text { are recognised (except in } \\
\text { impairments). }\end{array}$ \\
\hline $\begin{array}{l}\text { Mixed Model } \\
\text { (Current Model) }\end{array}$ & $\begin{array}{l}\text { All financial instruments are initially } \\
\text { measured at their fair value. For } \\
\text { subsequent measurements, the } \\
\text { model combines cost (or amortised } \\
\text { cost) with fair value (through profit } \\
\text { or loss or Other Comprehensive } \\
\text { Income - OCI), depending on } \\
\text { category classification. }\end{array}$ & $\begin{array}{l}\text { Apart from the initial recognition, fair value } \\
\text { is applied as the subsequent measurement } \\
\text { model for certain financial instruments. In } \\
\text { other cases, amortised cost (or cost) is } \\
\text { applied. Hedge accounting rules are applied } \\
\text { to avoid accounting asymmetries. Normally, } \\
\text { financial assets measured at amortised cost } \\
\text { or at fair value with changes in OCl should } \\
\text { be assessed for impairment (in which case } \\
\text { it is recognised against profit or loss). }\end{array}$ & $\begin{array}{l}\text { In some cases profit or loss and } \\
\text { in other cases Equity }(\mathrm{OCl}) . \\
\text { Depends on the categories: } \\
\text { realised results are recognised } \\
\text { and in some cases also } \\
\text { unrealised. }\end{array}$ \\
\hline $\begin{array}{c}\text { Full Fair Value } \\
\text { Model }\end{array}$ & $\begin{array}{l}\text { All financial instruments are initially } \\
\text { measured at their fair value. All } \\
\text { financial instruments are } \\
\text { subsequently measured at fair } \\
\text { value through profit or loss. }\end{array}$ & It is applied to all financial instruments. & $\begin{array}{l}\text { Profit or loss. } \\
\text { Both realised and unrealised } \\
\text { results are recognised. }\end{array}$ \\
\hline
\end{tabular}

Source: Compiled by the authors.

\section{RESEARCH METHODOLOGY}

We will essentially review fair value accounting literature and develop a critical and evaluative account of the different papers and studies that have been issued to date. We will only focus on papers and studies that develop an empirical approach, and that were published between the 1980s and the present-day.

The first step was to classify the literature according to lines of research. We found the lines of research that are included in the following table.

Table 2

Fair Value Research Lines

\begin{tabular}{|c|c|c|c|}
\hline Line & Brief description & Period & Paper section \\
\hline 1. Balance sheet modelling & $\begin{array}{c}\text { Analysis of which accounting model better reflects } \\
\text { risk management activities by using theoretical } \\
\text { balance sheets and income statements. }\end{array}$ & From 1996 to date. & Section 4 \\
\hline $\begin{array}{c}\text { 2. Fair value model } \\
\text { volatility }\end{array}$ & $\begin{array}{c}\text { Authors analyse whether fair value model } \\
\text { increases earnings volatility. }\end{array}$ & From 1995 to date. & Section 5 \\
\hline $\begin{array}{c}\text { 3. Relevance of fair value } \\
\text { disclosures (value } \\
\text { relevance literature) }\end{array}$ & $\begin{array}{c}\text { Authors analyse whether investors use fair value } \\
\text { information in order to make investment decisions. }\end{array}$ & From 1983 to date. & Section 6 \\
\hline $\begin{array}{c}\text { 4. Fair value relevance and } \\
\text { other variables }\end{array}$ & $\begin{array}{c}\text { Authors analyse the relationship between fair } \\
\text { value relevance and variables such as board } \\
\text { characteristics, institutional environment, } \\
\text { perceived risk, etc. }\end{array}$ & From 2013 to date. & Section 7 \\
\hline $\begin{array}{c}\text { 5. Fair value definition and } \\
\text { its components }\end{array}$ & $\begin{array}{c}\text { Discussion of IFRS 16/ ASC 820 fair value } \\
\text { definition components. }\end{array}$ & From 2014 to date. & Section 8 \\
\hline $\begin{array}{c}\text { 6. IFRS 13 I ASc 820 } \\
\text { disclosures quality }\end{array}$ & $\begin{array}{c}\text { Authors analyse whether new standards have } \\
\text { improved fair value disclosures, and if companies } \\
\text { are complying with their requirements. }\end{array}$ & From 2013 to date. & Section 9 \\
\hline
\end{tabular}

Source: Compiled by the authors. 


\section{BALANCE SHEET MODELLING}

This line of research fundamentally involves creating theoretical standard balance sheets and profit and loss accounts for companies based on real average company data. The objective is to analyse which accounting model better reflects a company's risk management activities (total risk hedge, partial risk hedge, no hedge, etc.) in different scenarios of changes in market variables.

These studies may be viewed in relation to relevance research and the Utility Paradigm, since they try to analyse which model offers more useful information (i.e., more accurately reflects reality) to the users of financial information.

The results usually show that the FFV model is the one that best reflects a company's hedging activities.

With regard to this line of research, we should mention that one of the most complete works is that of Gebhardt et al. (2004). It is also worth pointing to the research carried out by Hamida (2006) (focused on a specific French context), and the research carried out by Barth et al. (1996) as an antecedent in the US.

Gebhardt et al. (2004) carried out their study at a time when IFRS standards were beginning to be implemented in many banking institutions in Europe. These organisations were arguing that the new rules would not adequately reflect the economic activities of the banking sector. In this sense, according to Gebhardt et al. (2004, p.342), standard setters were facing strong opposition from the banking industry when proposing new standards that would change their preferred "mixed model" by introducing fair value measurements for all derivative instruments (SFAS 133, IAS 39), or by extending fair value accounting to all financial instruments, as recommended by the JWG.

The authors create the balance sheet of a "universal bank" (standard bank) which includes both typical commercial banking activities and those of an investment bank (based on data from German banks). In fact they divide the balance sheet in two: the banking book and the trading book. The bank is fully hedged against interest rate risk through derivatives (in particular through interest rate swaps).

They study the effect of changes in interest rates on the income statement in three possible accounting models: the IAS before IAS 39 became effective ("Old IAS"); the IFRS mixed model included in IAS 39 ("Current IAS or USGAAP"); and the model proposed by the JWG (FFV).

They find that under the "Old IAS" model, while the bank does reflect a zero economic earnings result in its income statement, a positive or negative result (with the same assets and liabilities composition) could nevertheless be obtained, due to the discretion allowed by the model. Under the "Current IAS", banks cannot accurately reflect their risk management policies because hedge accounting rules are excessively restrictive. According to the authors, it does not 
allow best-practice asset liability management activities to be adequately reflected in the financial statements (Gebhardt et al., 2004, p.342). Finally, under the FFV Model, the fully hedged bank has to present zero net income; if the bank hedges only part of its risks, this will result in non-zero net income. The model does not allow discretion in presenting the results of banking operations.

On the other hand, Hamida (2006) creates a model similar to that of Gebhardt et al. (2004), but based on French banks and comparing income statement results of entities before and after IFRS adoption in the EU. Regarding market variables, the study is based on the context of a generalised decrease in interest rate levels.

The author tests a hypothetic bank model which includes the universal items that may be found on banks' balance-sheets. In order to reduce the complexity of the model, the focus is limited to interest rate products either belonging to the trading or the banking book, and to interest rate risk management. Hamida simulates his standard financial statements in order to study and analyse the impacts of IAS 39 application in terms of volatility, using all possible options (cash flow hedge and fair value hedge).

Hamida found that under "Current IAS or US GAAP", banks cannot adequately portray their investment banking and commercial banking activities due to the restrictive hedge accounting rules, which do not allow best-practice asset liability management activities to be adequately reflected in the financial statements.

He demonstrates that the application of JWG's FFV adequately reflects the economics of banking activities. The fully hedged bank has to present zero net income: if the bank hedges only part of its risks, this will result in non-zero net income. The model does not allow discretion in presenting the results of banking operations.

\section{FAIR VALUE MODEL VOLATILITY}

A line of research which is close to the balance sheet modelling line is that which analyses whether the fair value model entails a higher earnings volatility.

Barth et al. (1995) and Hodder et al. (2006) document an increase in earnings volatility due to fair value accounting. For example, Hodder et al. (2006) use a sample of 202 commercial banks in the US (from 1996 to 2004) and reconstruct the FFV model net income and comprehensive income using fair value disclosures under SFAS 107 and SFAS 133 (see Section 6). They find that, for the average sample bank, the volatility of full fair value income is more than three times that of comprehensive income, and more than five times that of net income. They suggest that full fair value income volatility reflects elements of risk that are not captured by volatility in net income or comprehensive income, and that it relates more closely to the capital market pricing of that risk than either net income volatility or comprehensive income volatility. 
Fiechter (2011) focuses on the application of IAS 39 Fair Value Option $(\mathrm{FVO})^{13}$ by banks. The author uses a sample of 222 international banks from 41 countries that apply IFRS and obtain data regarding the application intention of FVO from the disclosure section contained in annual reports from 2007. He then tests whether banks that apply FVO primarily to reduce accounting mismatches exhibit lower earnings volatility during the period from January 2006 until December 2007. He uses an earnings volatility proxy that is based on reported earnings, instead of retrospectively adjusted fair value income measures or simulation analyses.

This study provides empirical evidence that demonstrates that the effects of FVO on earnings volatility should be assessed based on the application intention. Banks applying FVO primarily to reduce accounting mismatches report lower levels of earnings volatility than the control group, although the FVO is irrevocable.

Couch et al. (2014) carried out similar research but focused on a sample of companies from the US which were applying FVO under SFAS 159 (which became effective in 2008) ${ }^{14}$. They measured the change in earnings volatility as the growth of quarterly operating income volatility over the four years prior to and the four years following 2008. They used a sample of 556 financial entities, out of which 90 were SFAS 159 adopters. They found that a large subset of FVO adopters with fair value assets and no fair value liabilities experience an increase in earnings volatility, which they argue is attributable to the adoption of FVO.

\section{RELEVANCE OF FAIR VALUE DISCLOSURES}

\subsection{Value Relevance Literature}

The basic objective of this line of research is in general terms to obtain empirical evidence regarding the extent to which information about unrecorded fair values ${ }^{15}$ (positive or negative revaluation of items) is used by investors for decision making. For this purpose, the authors analyse whether such information contributes to explaining the difference between the book value of the company's equity and its market quoted value. In other words, the authors analyse whether

\footnotetext{
${ }^{13}$ Under IAS 39, a company can voluntarily elect to subsequently measure any financial asset of financial liability at fair value through profit or loss in certain cases, i.e. if this measurement basis reduces accounting asymmetries or if the element is part of a portfolio whose performance is evaluated on a fair value basis. In IFRS 9, FVO for financial liabilities remains the same (except for the fact that changes in value due to own credit risk are recognised in OCI), and FVO for financial assets is only applicable for reducing accounting asymmetries.

${ }^{14}$ SFAS 159 introduced FVO in USGAAP. It should be noted that FVO under USGAAP is less restrictive than under IAS 39.

${ }^{15}$ As disclosed in the notes to the financial statements.
} 
the fair value contains more information than the cost (that is, if it is more "relevant").

From the perspective of the income statement, several authors have also analysed whether returns that include all changes in fair value (result under an FFV Model) imply a higher level of explanation and prediction with regard to changes in market prices compared with current accounting results (result under a Cost Model or a Mixed Model).

This type of empirical research emerges within the framework of the Utility Paradigm, and in the context of the evolution of the objective of accounting standards towards the issuance of useful information for investment decision making and for the projection of future cash flows of the company Within this context (and especially since the 1980s), the authors attempt to analyse the reliability and, above all, the relevance of the fair value, since these were the two characteristics upon which the FASB started to be based in order to choose between alternative accounting treatments $\left(\mathrm{SFAC}^{16} 2,1980\right)$.

The statistical model used by the different authors is usually related to the accounting equation under which it is assumed that the company's quoted value (on a stock exchange) is explained by the sum of the values of the assets and liabilities (including the effect of goodwill, especially in research papers issued from the 1990s). Many of the bases of the model were formulated by Ohlson (1980) and especially Ohlson (1995), and since then the applied econometric model is usually known as "Ohlson's Model" or as a variant thereof. In fact, the Ohlson Model has been widely used in various types of empirical accounting research. As pointed out by Larrán and Piñero (2005, p.116), a review of the main accounting research journals oriented to the capital market highlights the fact that an extremely large number of studies have adopted this assessment framework for the empirical testing of their hypothesis or for the development of new contributions of a theoretical nature.

Initial research began in the 1980s following the issuance of SFAS 19 (1977) and SFAS 33 (1979) by the FASB. SFAS 19 required companies in the oil and gas sector to disclose certain data concerning their fuel reserves (including an estimate of their market value). SFAS 33 required all companies of a certain size to disclose an estimation of the "current cost" for several types of assets (mainly inventories and fixed assets).

Much of this early research did not find relevant empirical evidence regarding the relevance of fair value estimates. The general explanation for this result was that the estimations prepared by companies included errors. Some studies also point to the problem of using data from different sectors at the same time. For the authors concerned, the result of their research work was "unexpected".

${ }^{16}$ Statement of Financial Accounting Concepts (SFAC). 
Within this context (in relation to SFAS 19), Harris and Ohlson (1987), as along with Magliolo (1986), use statistical models, and they reach the conclusion that the book values of the "oil \& gas" assets (based on cost and not on fair value) are relevant when explaining the market value of the company's equity, even more so than the information disclosed in the notes concerning the current value measurement of the different items ("standardized present value"). Harris and Ohlson (1987), for example, use data from a range of 49 to 62 companies (depending on availability per year) over a time period from 1979 to 1983.

On the other hand, and with regard to SFAS 33 disclosures, Beaver and Landsman (1983) Beaver and Ryan (1985), along with Bernard and Ruland (1987) all find evidence that demonstrates that the fair values disclosed do not entail an additional explanatory capacity for the share prices when compared to book values. Bernard and Ruland (1987) are those that use a broader sample: 113 entities over 19 years (1962 to 1980) because they obtain data not only from discloses required by SFAS 33, but also from the information issued under SEC Accounting Series Release No. 190.

Barth et al. (1996, p.516) would later highlight how several studies conclude that errors in estimating SFAS No. 33 amounts account for the generally insignificant findings regarding their incremental explanatory power. Consistent with the concerns raised by these research, the FASB eliminated the disclosure requirements.

In December 1991, the FASB issued SFAS 107, which required the disclosure (in the notes to the financial statements) of the fair value of all financial instruments which were not measured at fair value on the statement of financial position. This suggested that the FASB assumed that the information offered by fair value was relevant (at least in relation to financial instruments). The new information that entailed the issuance of this standard (i.e., the new information that companies disclosed) facilitated a second group of empirical studies whose objective was to demonstrate this FASB assumption.

Following what occurred following SFAS 33 (that is, following the results of the abovementioned research), many authors questioned whether the information offered by SFAS 107 would be relevant and reliable. However, there were several differences between SFAS 33 and SFAS 107, such as:

- The disclosures under SFAS 107 needed to be audited (unlike SFAS 33).

- SFAS 107 refers to financial instruments, while SFAS 33 refers to inventories and fixed assets (in principle, fair value is expected to be more reliable in financial instruments).

- SFAS 33 was limited to assets (without including liabilities), hence the models omitted variables when analysing the explanatory capacity of the disclosures. 
One of the first instances of research that analysed the relevance of the information offered by SFAS 107 was Barth (1994).However, the data used was not SFAS 107 disclosures. The study focused only on investments in debt instruments that US banks ${ }^{17}$ classified as held to maturity (investment securities - basically state or municipal public debt), which were measured at cost in the statement of financial position, and whose fair value had been disclosed some time before.

Barth analyses how the fair values of investments in securities (and their associated gains and losses) are reflected in the prices of the bank's shares as compared to the acquisition price. Her aim is to determine which of the amounts (fair value or cost) is more relevant and reliable for investors when valuing the bank's equity. The data used covers a period from 1971 to 1990 for a total of approximately 90 banks. She finds that, as regards investments in securities, fair value has more explanatory power than cost. In relation to the gains and losses related to fair value, she finds that they are estimated with a level of error sufficient to make it difficult to establish its relevance (in line with previous SFAS 33 and SFAS 19 research).

Subsequently, Eccher et al. (1996) and Nelson (1996) analyse the valuerelevance of the disclosures under SFAS 107 in the US banking sector (using a sample of 200 and 300 entities, respectively). Nelson (1996) evaluates the relationship between the market value of the bank's equity (based on the quoted share price) and the fair values of the assets and liabilities disclosed under SFAS 107. He concludes that the fair value disclosures do not generally have an incremental explanatory capacity with respect to the cost of securities, loans, deposits, long-term debts and off-balance-sheet operations. The possible exception would perhaps be investments in securities in certain circumstances. Eccher et al. (1996), in a similar study, only find incremental explanatory capacity for investments in securities.

However, in a further similar study, Barth et al. (1996) find that the explanatory capacity of the disclosures under SFAS 107 (especially as regards loans) is more robust than that inferred in previous studies. More specifically, according to data obtained by Barth et al. (1996) for 136 US banks, the fair value estimates are significantly associated with the difference between the market value and the book value for a sample of banks on both the dates on which the sample is based (1992 and 1993). With regard to the loans, Barth et al. (1996) obtain a positive and statistically significant coefficient for both years. The coefficient of investments is also significant, but the coefficients associated with deposits and off-balance sheet instruments are not significant.

${ }^{17}$ As we will see, practically all empirical studies of this type are based on banks and similar institutions because their balance sheet is largely composed of financial instruments. 
The basic difference between the studies of Eccher et al. (1996) and Nelsol (1996) on the one hand, and Barth et al. (1996) on the other, lies in the fact that the latter include an approximation of variables in the model that could affect goodwill value. In other words, the authors attempt to model goodwill as an additional variable explaining the fair value of the entity's equity.

Simko (1999) analyses the relevance of the disclosures under SFAS 107 to approximately 260 non-financial entities for the period from 1992 to 1995. His conclusion is that the fair value disclosures of liabilities, which consisted mainly of long-term debt, are statistically significant when explaining the market value of the company.

SFAS 115 (1993) required securities to be classified in two categories "available for sale" and "held to maturity" - depending on the intention of the entity in relation to said securities. Subsequent measurement of a security was at fair value or amortised cost depending on its classification. Park et al. (1999) examine whether the intent-based fair value disclosures by security type may explain the value of bank equity, finding that both available for sale and held for maturity value differences (fair less book values) explain the value of bank equity. The available for sale value differences also explain raw stock returns and abnormal returns, while the held to maturity value differences explain only the raw returns.

Khurana and Kim (2003) analyse the relevance of the fair value estimates under SFAS 107 over a different period of time, from 1995 to 1998. They use a sample of 302 bank holding companies, and carry out a regression analysis comparing the fair value/book value of assets and liabilities and the market value of equity. Their results show that historical cost contains more nformation than fair value for banks classified as small and for which no important external analysis exists. The areas in which the cost does confer more information than the fair value are loans and deposits. For the authors, the results are consistent with the fact that fair value is more relevant when quoted prices are used to obtain them (and not internal models).

Finally, Evans et al.'s (2014) study of a sample of banks over the period 1994 to 2008 finds that banks' accumulated fair value adjustments for investment securities are positively associated with reported income from those financial instruments in the following period (which they refer to as the "predictive ability" of fair values). They also find that these adjustments have predictive ability for investment-security-related cash flows in the subsequent period. These financial instruments' fair values should be cross-sectionally related to the relative future interest income realised from the instruments since fair values capture expected opportunity costs and opportunity benefits of holding the specific cash flow rights of financial instruments. 
Especially since the 1990s, a period during which the volume of derivatives entered into by the companies experienced a significant increase and large losses were experienced by companies due to derivatives, certain authors applied the "Ohlson Model" to the information regarding derivatives. The FASB issued SFAS 119 in 1994 and SFAS 133 in 1998 (although the latter was not applicable until June 2000). SFAS 119 obliged companies to disclose some information concerning derivatives (nominal amount, company's intention, categories, etc.), and subsequently SFAS 133 required all derivatives to be measured on the balance sheet at fair value (and permitted the application of hedge accounting rules).

Wang et al. (2005) conduct empirical research with regard to the relevance of derivative disclosures under SFAS 119 and SFAS 133. They use a series of continuous data from banks from 1994 to 2002. The results show that the disclosed information regarding the nominal amount of the derivatives is value relevant, i.e. it offers incremental information regarding the book value and the results.

Meanwhile, empirical studies in which the Ohlson Model was applied began to appear in Europe, especially once IFRS standards were adopted for the consolidated statements of listed companies in 2005. In this respect, we may point out research such as that of Aurori et al. (2012). The authors apply a variant of the Ohlson Model (1995) to the data of 25 companies quoted in the CAC 40. They conclude that the volatility of the net income under the fair value model (using the disclosures of the financial statements) does not significantly affect the determination of quoted prices; rather it only increases the perception of risk by market operators. Drago et al. (2013) use data from 83 European banks for the period from 2005 to 2008. They find that book values and earnings affect banks' market values. Investors consider the difference between loan book and fair values, and attribute to this difference an expected negative value.

\subsection{Relevance of Fair Value Levels}

This line of research is related to the classification of financial instruments in Levels 1, 2 and 3 by companies (under IFRS 7, IFRS 13 and ASC 820). The FASB and the IASB created a fair value hierarchy that includes three levels:

- Level 1: fair value is obtained through quoted prices (unadjusted) in active markets for assets or liabilities identical to those that the company is measuring.

- Level 2: a valuation model is used in which all the significant inputs are observable in the market. Examples include: quoted prices for similar assets or liabilities in active markets; quoted prices for identical or similar assets or liabilities in non-active markets; other observable inputs that are 
incorporated into a valuation model (interest rates, implicit volatilities, credit spreads), etc.

- Level 3: a valuation model is used where at least one significant input is not observable in the market (i.e. it is internally developed by the company).

Since the issuance of SFAS 157 (ASC 820) and IFRS 7, financial instruments that are measured at fair value on the balance sheet must be classified in one of the three previous levels. Subsequently, this requirement was extended to all financial instruments (regardless of their valuation method on the balance sheet), because in all cases the fair value must at least be disclosed.

There are a number of studies that analyse, in one way or another, the links between the fair value hierarchy and financial markets. Several authors analyse the relevance of fair value (value relevance, see Section 6.1 above), but specifically focusing on the hierarchy of levels established by accounting standards. In general terms, the results show that all levels are relevant (Level 1 being the most relevant), and that Level 3 assets are valued by the market at a discount compared to their book value. This difference is due to general market conditions (during financial crises the differences would be higher, for example), or to market/model limitations as a whole, and is not due to the fact that Level 3 estimates are less reliable or relevant on their own.

Kolev (2008) uses a sample of 177 US financial institutions from the first quarter of 2008 along with 172 from the second quarter, and analyses whether Level 2 and Level 3 fair values are value relevant. The model used relates the market value of each company (through the quoted value of the shares) to the net assets broken down into levels according to the fair value hierarchy. It consists of a balance sheet model similar to that described in the previous section, but focused on the relevance of each level. Further variables that Kolev includes in the model are other assets not measured at fair value and control variables.

Kolev finds that the coefficients assigned by the model to Levels 2 and 3 are lower than the coefficient of Level 1 (which is close to 1). His conclusion is that the assumptions made by the company's management are sufficiently reliable to be reflected in the quoted share prices. Despite the fact that investors put less trust in Level 2 and Level 3 fair values as compared to Level 1, the difference is significant (but does not exceed 35\% at its peak) only for the Level 3 estimates, and those mark-to-model estimates can be used quite reliably and not discarded.

Subsequently, Goh et al. (2015) concluded, like Kolev (2008), that in the US financial instruments valued with valuation techniques (Levels 2 and 3) are reflected in the market value of the company with a discount, probably due to its low liquidity and because of the high risk of the lack of information. Although there is a positive relationship between the entity's share prices and all three levels, the coefficients are below the unit, and more significantly so in 
Levels 2 and 3. These results are consistent with other studies (such as Coval et al., 2008 and Longstaff and Rajan, 2009), which suggest that the assets valued with models (mark-to-model) are overvalued in relation to their market value.

Song et al. (2010) analyse the relevance of fair value disclosures according to the three levels using a statistical model of correlations. They use the data corresponding to the first three quarters of 2008 for a sample of 431 banks quoted in the US. They find that the relevance of Levels 1 and 2 is greater than the relevance of Level 3 (Level 3 information is relevant nonetheless). Investors are likely to value mark-to-model estimates less, possibly because of information asymmetry and moral hazard problems. Additionally, the relevance of fair values (especially in the case of Level 3) is greater in the case of companies with stronger corporate governance (see also Vyas, 2010).

Song (2015) uses the modified Ohlson Model (1995) and a sample of 670 US financial companies for the period from 2008 to 2013. He finds that market volatility affects how investors price fair values, and especially fair values based on market inputs. More specifically, investors discount market-based Level 1 and Level 2 fair values significantly when market volatility is high. Investor pricing of non-market-based Level 3 fair values is not affected by market volatility.

Lawrence et al. (2016) attempt to re-evaluate the conclusion that Level 3 fair value measurements are significantly less value-relevant than Level 1 and Level 2 fair value measurements. They use the closed-end fund setting, in which almost all assets are measured at fair value. Contrary to prior research, they find that Level 3 fair values are of similar value relevance to Level 1 and Level 2 fair values. Their findings suggest that results of previous research are attributable to correlated omitted variable bias arising from the absence of fair value data for most assets.

Du et al. (2014) compare banks that make transfers of elements in and out of the Level 3 category when Level 1 and Level 2 inputs are not available with banks that do not make such transfers. They find that there is a significant increase in value relevance of all three fair value levels in the case of all banks that do make transfers compared to those banks that do not make such adjustments.

At the European level, Bosch (2012) analyses the relevance of fair value based on IFRS 7 fair value hierarchy and the Ohlson Model (1995). Using a sample of European banks, he concludes that all three levels are relevant for investors, although Level 3 is usually perceived as less reliable than the others (as demonstrated by a lower regression coefficient and by being statistically different Levels 1 and 2).

Laghi et al. (2012) use a sample of financial statements from listed banks in Europe, the US and the rest of the world (for the period 2009 to 2011) in order 
to analyse whether fair value hierarchy ( classification by levels) increases the transparency of financial information. They use a statistical model that aims to analyse the explanatory power of the three levels on the quoted value of the company and its results. Likewise, they study whether there is a relationship between the annual variation in the value of the Level 1 portfolio and the annual variation of the Level 2 and 3 portfolios.

The conclusions of the authors include the following: (1) disclosures into levels was not yet being widely used by the entities: of a sample of 2,500 listed banks, only 281 carried out the classification; (2) instruments in Level 3 show little relevance when it comes to explaining the market value of the company or the results; (3) there is no correlation between the performance of Level 1 and the performance of Levels 2 and 3.

Other authors, using a different perspective, focus on the subjectivity of the fair value model by studying the classification of financial instruments at previous levels. In this sense, one of the objections that tends to be attributed to the fair value model is its lack of subjectivity. The higher the percentage of assets and liabilities included in Level 3, the greater the level of general subjectivity of the model.

By way of example, the SEC (2008) carried out a global study in which, among other analyses, it studied the use of fair value by US financial institutions. Using data from US entities in the first and third quarters of 2008, it concluded that on average $76 \%$ of assets are classified in Level 2; $15 \%$ in Level 1; and only $9 \%$ in Level 3. As regards liabilities, approximately $84 \%$ were classified as Level 2; $11 \%$ as Level 1; and 5\% as Level 3.

\section{FAIR VALUE RELEVANCE AND OTHER VARIABLES}

Several authors analyse the relationship between fair value relevance/fair value hierarchy levels and other variables such as corporate governance, board characteristics, institutional environment, etc.

In the previous section we saw how Song et al. (2010) found that the relevance of fair values (especially in the case of Level 3) is greater in those companies with stronger corporate governance.

Siekkinen (2017) investigates whether board characteristics affect the value relevance of fair value estimates in financial companies under IFRS 13. The results indicate that, in a post-IFRS 13 era, board independence and gender diversity have a positive effect on the value relevance of fair value estimates (Level 3). Additionally, firms with larger boards have lower information quality of firm-generated fair value estimates. Moreover, initial analysis shows that all fair values are value relevant to investors, and that the adoption of IFRS 13 has blurred the lines between the three levels in the fair value hierarchy. Hence, 
IFRS 13 has successfully reduced the information asymmetry related to fair value estimates.

Fiechter and Zoltán (2017) analyse whether the value relevance of the fair value categories under IAS 39 (i.e. $\mathrm{HFT}^{18}$, FVO, and $\mathrm{AFS}^{19}$ ) varies across institutional environments. They use a sample of 907 bank-years (2006 to 2009) from 46 countries worldwide. They find that FVO assets are generally less value relevant than HFT and AFS assets. This differential value relevance is particularly pronounced in bank-based economies. A richer firm-level information environment, combined with the presence of Nordic institutional investors with fair value experience significantly improve the value relevance of FVO assets in bank-based economies. Therefore, they attribute our findings to institutional frictions (i.e. weak information environment and little experience with fair values), limiting investors' ability to properly process fair value information.

Another line of research connects fair value relevance with credit rating. It analyses the relationship between fair value disclosures and credit ratings/investor's perceived risk. Certain authors attempt to explain the credit rating of firms with an econometric model that includes fair value levels and other disclosures.

Ayres et al. (2017) find that a higher amount of assets classified as Level 3 negatively impacts credit ratings. This relation becomes more significant for companies with greater financial leverage, suggesting that a primary determinant of credit risk amplifies the documented main effect. Higher amounts of assets classified as level 3 are associated with an economically meaningful increase of corporate bond spreads.

Blankespoor et al. (2013) find that leverage measured using the fair values of financial instruments explains significantly more variation in bond yield spreads and bank failure than other less fair-value-based leverage ratios in both univariate and multivariate analyses. The fair value of loans and deposits appear to be the primary sources of incremental explanatory power.

Relevance for analysts' forecasting is another subject that has been studied in fair value literature, mainly in SFAS 157 application. These studies use explanatory models of analysts' forecast accuracy.

Ayres et al. (2017) find that firms with higher percentage assets and liabilities measured at fair value have more accurate analyst earnings forecasts, with positive associations between analysts forecast accuracy and Level 1 and 2 fair value measurements. However, they do not find such association for Level 3 measurements. These effects are predominantly concentrated in non-financial industry firms. Their results suggest that qualitative features of fair value

\footnotetext{
${ }^{18}$ Held for trading.

${ }^{19}$ Available for Sale.
} 
measurements could also have an impact on analyst forecasting accuracy beyond mere measurement issues.

In relation to the utility of Level 3, Barron et al. (2016) provide evidence suggesting that FAS 157 disclosures regarding Level 3 measurements are able to reduce uncertainty in analysts' information environment. The provision of such fair value disclosures are associated with reduced uncertainty regarding future earnings and lower forecast errors. These values are positively associated with firms' future performance.

Liang and Riedl (2014) find higher net asset value forecast accuracy for UK firms as compared to US firms, consistent with the fair value reporting model revealing private information that is incorporated into analysts' balance sheet forecasts. This difference is attenuated when the fair value and historical cost models are more likely to converge, i.e. during recessionary periods. They find a lower earnings per share forecast accuracy for UK firms when reporting under the full fair value model of IFRS, in which unrealized fair value gains and losses are included in net income.

Magnan et al. (2015) examine whether and how fair value measurement and disclosure by US bank holding companies influences financial analysts' ability to forecast earnings. Fair value measurement relates to more dispersed forecasts. Measurement basis disclosure (Levels 1, 2 and 3) enacted by SFAS 157 translates into more accurate forecasts, but has neutral effects for banks with a sizeable proportion of assets at fair value. Furthermore, Level 2 measurement relates to enhanced forecast accuracy, while Level 3 measurement relates to increased forecast dispersion.

\section{FAIR VALUE DEFINITION AND ITS COMPONENTS}

This line of research focuses on analysing the different aspects of fair value definition (exit price) included in IFRS 13/ASC 820 and, in many cases, its practical application.

Prior to the issue of IFRS 13/ASC 820, a comprehensive fair value definition did not exist. It was defined in several ways according to the different standards that required or permitted fair value measurement. Once the FASB and the IASB issued ASC 820 and IFRS 13 and unified fair value concept and definition, authors analysed different aspects of this definition.

By way of example, over the last 5 years, certain authors have analysed whether XVA should also be considered when estimating fair value for financial instruments under IFRS 13/ASC 820, and how it should be considered. XVA stands for "X" value adjustments such as KVA (Capital Value Adjustment); CVA (Credit Value Adjustment); DVA (Debit Value Adjustment); FVA (Funding Value Adjustment); and MVA (Margin Valuation Adjustment). 
These studies were carried out essentially due to the many practical discussions that have arisen in the market in this field, in some cases due to the influence of the Prudent Valuation as required by the EBA (European Banking Authority).

Hull and White (2014) examine whether a bank should make a funding value adjustment (FVA) when valuing derivatives. They conclude that an FVA is justifiable only for the part of a company's credit spread that does not reflect default risk. Keyton and Keyton (2016) analyse the applicability of KVA and propose an accounting treatment of the economic effects of KVA in accordance with IFRS 13. Morales (2015) discusses the different methodologies for calculating CVA and DVA for derivatives and its applicability under IFRS 13.

\section{IFRS 13/ASC 820 DISCLOSURES QUALITY}

This line of research analyses whether IFRS 13 has improved previous fair value disclosures in financial statements, and whether companies are complying with IFRS 13 in this respect.

Matis et al. (2013) analyse diversity in fair value disclosures and its determinant factors. They use a sample of 20 companies listed on the London Stock Exchange and the Frankfurt Stock Exchange. They prepare a guide of best practices and focus on empirically documenting potential determinants. In order to achieve the objective of the study, they calculate a disclosure score - known as the disclosure index - for each company included in the study. Subsequently, using a statistical program, they run a multivariate linear regression. The results obtained demonstrate, among other things, that the size of the entity positively affects the fair value measurements disclosure index.

Busso (2014) focuses on the European real estate sector, and finds that disclosures concerning fair value measurement required by IFRS 13 are reported by many entities, but that there are companies which are still not compliant with the new requirements.

Chung et al. (2017) examine whether fair value disclosures improve investors' perception regarding the reliability of fair value estimates, and find that they are associated with higher market pricing and lower information risk for Level 3 estimates. Discussion of the external and independent pricing of fair value estimates, and the estimates' proper classification according to the SFAS 157 hierarchy reveal are particularly important to investors. The authors conclude that the voluntary reliability disclosures that firms provide beyond SFAS 157's threelevel estimates help to reduce investors' uncertainty towards the more opaque fair value estimates.

Yao et al. (2016) find that the use of discretionary Level 3 valuation inputs are related to earnings management, determined by firm-level and country-level. 


\section{CONCLUSION}

We have conducted a comprehensive analysis of fair value literature, principally focusing on fair value relevance and financial instruments.

Firstly, we have classified papers according to six different lines of research pertaining to the authors' main objective. Secondly, we have analysed each of the above-mentioned lines of research in order to evaluate the main findings obtained by the authors in each case.

The following table includes a brief summary of the main findings for each line of research.

Table 3

Fair Value Research Lines - Conclusions

\begin{tabular}{|c|c|c|}
\hline Line of research & $\begin{array}{c}\text { Section of } \\
\text { paper }\end{array}$ & General conclusion \\
\hline $\begin{array}{c}\text { 1. Balance sheet } \\
\text { modelling }\end{array}$ & Section 4 & The FFV model is the one that better reflects companies' hedging activities. \\
\hline $\begin{array}{c}\text { 2. Fair value model } \\
\text { volatility }\end{array}$ & Section 5 & The fair value model entails a higher volatility. FVO can reduce volatility. \\
\hline $\begin{array}{c}\text { 3. Relevance of fair value } \\
\text { disclosures (value } \\
\text { relevance literature) }\end{array}$ & Section 7 6 & $\begin{array}{c}\text { Although different research has reached different conclusions, we can state } \\
\text { that generally speaking, information offered by fair value to investors is } \\
\text { relevant. Level 1 and Level 2 fair values are more relevant than Level 3. }\end{array}$ \\
\hline $\begin{array}{c}\text { 4. Fair value relevance and } \\
\text { other variables }\end{array}$ & $\begin{array}{c}\text { The relevance of fair value information may be affected by factors such as } \\
\text { board characteristics or institutional environment, but to date there is still } \\
\text { little research in this area. Fair value information is relevant for analysts. }\end{array}$ \\
\hline $\begin{array}{c}\text { 5. Fair value definition and } \\
\text { its components }\end{array}$ & Section 8 & $\begin{array}{c}\text { Much debate exists with regard to the consideration of "XVA" adjustments in } \\
\text { fair value measurements. There is a general consensus in relation to } \\
\text { CVA/DVA adjustments. }\end{array}$ \\
\hline $\begin{array}{c}\text { 6. IFRS 13 I ASC 820 } \\
\text { disclosures quality }\end{array}$ & Section 9 & $\begin{array}{c}\text { In general, IFRS 13/ASC 820 adoption has increased fair value disclosures. } \\
\text { Different results show how companies in different sectors are complying with } \\
\text { these standards. }\end{array}$ \\
\hline
\end{tabular}

Source: Compiled by the authors.

\section{BIBLIOGRAPHY REFERENCES}

AURORI, M.H., BELLALAH, N.H. and NGUYEN, D.K., (2012). "Relevance of Fair Value Accounting for Financial Instruments: Some French Evidence". International Journal of Business, 17(2), pp. 209-220.

AYRES, D., HUANG, X. and MYRING, M. (2017). "Fair value accounting and analyst forecast accuracy". Advances in Accounting, 37, pp. 58-70.

BARRON, O.E., CHUNG, S.G., and YONG, K.O. (2016). "The effect of Statement of Financial Accounting Standards No. 157 Fair Value Measurements on Analysts' Information Environment". Journal of Accounting and Public Policy, 35(4), pp. 395416.

BARTH, M.E. (1994). "Fair Value Accounting: Evidence from Investment Securities and the Market Valuation of Banks". The Accounting Review, 69(1), pp. 1-25.

BARTH, M.E., LANDSMAN, W. and WAHLEN, J. (1995). "Fair value accounting: Effects on banks' earnings volatility, regulatory capital, and value of contractual cash flows". Journal of Banking \& Finance, 19(3-4), pp. 577-605. 
BARTH, M.E., BEAVER, W.H. and LANDSMAN, W.R. (1996). "Value-Relevance of Bank's Fair Value Disclosures under SFAS No. 107". The Accounting Review, 71(4), pp. 513537.

BEAVER, W.H. and LANDSMAN, W.R. (1983). "Incremental Information Content of Statement 33 Disclosures". FASB. Stamford, CT.

BEAVER, W.H. and RYAN, S. (1985). "How well do Statement No.33 earning explain stock returns?". Financial Analysts Journal, 41 (5), pp. 66-71.

BERNARD, V.L. and RULAND, R. (1987). "The incremental information content of historical cost and current cost income numbers: Time series analyses for 1962-1980". The Accounting Review, 62(4), pp. 707-722.

BLANKESPOOR, E., LINSMEIER, T.J., PETRONI, K.R. and SHAKESPEARE, C. (2013). "Fair Value Accounting for Financial Instruments: Does it Improve the Association Between Bank Leverage and Credit Risk? Accounting Review, 88(4), pp. 1143-1177.

BONA, E., VIEIRA, L., GUERRA, M. and DAL-RI, F. (2017). "International Studies About Fair Value (2000-2016): Themes, Methods and Suggestions for Future Research". Journal of Education and Research in Accounting, 11(3), pp. 270-289.

BONACI, C.G. and TUDOR, A.T. (2011). "Fair Value Empirical Studies: An Overview on Accounting Research Literature". Annales Universitatis Apulensis Series Oeconomica, 13(2), pp. 197-206.

BOSCH P., 2012. "Value Relevance of the Fair Value Hierarchy of IFRS 7 in Europe How reliable are mark-to-model Fair Values?". Working Paper, University of Friburg. http://doc.rero.ch/record/30782/files/WP_SES_439.pdf [last consultation: 25/11/2017]

BUSSO, D., (2014). "Does IFRS 13 Improve the Disclosure of the Fair Value Measurement?" Journal on Business Review, 3(4), pp.1-7.

CAIRNS, D. (2006). "The Use of Fair Value in IFRS". Accounting in Europe, 3(1), pp. 5-22.

CAÑIBANO, L., GARCÍA, M. and SÁNCHEZ, M. P. (1999). "La Relevancia de los Intangibles para la Valoración y la Gestión de Empresas: Revisión de la Literatura". Revista Española de Financiación y Contabilidad, 28(100), pp. 17-88.

CHUNG, S.G., GOH, B.W., NG J., YONG K.O. (2017). "Voluntary Fair Value Disclosures Beyond SFAS 157's Three-level Estimates". Review of Accounting Studies, 22(1), pp. 430-468.

COUCH, R., THIBODEAU, N. and WU, W. (2014). "Are Fair Value Options Created Equal? A Study of SFAS 159 and Earnings Volatility". Available at: https://ssrn.com/ abstract=2389742 [last consultation: 09/12/2017]

COVAL J. D., JUREK J. W. and STAFFORD E. (2008). "Economic catastrophe bonds". HBS Finance Working Paper No. 07-102. Available at: https://ssrn.com/abstract= 995249 [last consultation: 17/09/2017]

DRAGO, D., MAZZUCA M. and TRINA, R. (2013). "Do loans fair value affect market value? Evidence from European banks ". Journal of Financial Regulation and Compliance, 21(2), pp. 108-120.

DU H., LI S.F. and XU Z.R. (2014). "Adjustment of valuation inputs and its effect on value relevance of Fair Value measurement". Research in Accounting Regulation, 26(1), pp. 54-66.

ECCHER, A., RAMESH, K. and THIAGARAJAN, S.R. (1996). "Fair Value Disclosures by Bank Holding Companies". Journal of Accounting and Economics, 22(3), pp. 79-117. 
EMERSON, D., KARIM, K. and RUTLEDGE, R. (2010). "Fair Value Accounting: A Historical Review of the Most Controversial Accounting Issue in Decades". Journal of Business \& Economics Research, 8(4), pp. 77-86.

EVANS, M.E., HODDER, L. and HOPKINS, P.E. (2014). "The Predictive Ability of Fair Values for Future Financial Performance of Commercial Banks and the Relation of Predictive Ability to Banks' Share Prices". Contemporary Accounting Research, 31(1), pp. 13-44.

FIECHTER, P. (2011). "The Effects of the Fair Value Option under IAS 39 on the Volatility of Bank Earnings". Journal of International Accounting Research, 10(1), pp. 85-108.

FIECHTER, P and ZOLTÁN, N-F. (2017). "The Impact of the Institutional Environment on the Value Relevance of Fair Values". Review of Accounting Studies, 22(1), pp. 392429.

FORTIN, S. (2005). "Relevant and Reliable? Fair Value Accounting for Financial Instruments: What can be Concluded from Academic Evidence". CA Magazine, 138(2), pp. 45-47.

GEBHARDT, G., REICHARDT, R. and WITTENBRINK, C. (2004). "Accounting for Financial Instruments in the Banking Industry: Conclusions from a Simulation Model". European Accounting Review, 13(2), pp. 341-371.

GOH B.W., LI, D., NG J. and OW YONG K.K. (2015). "Market pricing of banks' fair value assets reported under SFAS 157 during the 2008 Economic Crisis". Journal of Accounting and Public Policy, 34(2), pp. 129-145

HAMIDA, N.B. (2006). "Banking accounts volatility induced by IAS 39: A simulation model applied to the French case". Available at: http://basepub.dauphine.fr/bitstream/ handle/123456789/2187/Ben_hamida.pdf?sequence=2 [last consultation: 17/09/2017]

HARRIS, T.S. and OHLSON. J.A. (1987). "Accounting Disclosures and the Market's Valuation of Oil and Gas Properties". The Accounting Review, 62(4), pp. 651-670.

HERZ, R.H. (2013). "Accounting Changes". AICPA, Durham, NC (USA).

HODDER, L., HOPKINS, P., and WAHEN, J. (2006). "Risk-relevance of Fair-Value Income Measures for Commercial Banks". The Accounting Review, 81(2), pp. 337375.

HODDER, L., HOPKINS, P., and SHIPPER, J. (2014). "Fair Value Measurement in Financial Reporting". Foundations and Trends in Accounting, 8(3-4), pp. 143-270.

HULL, J. and WHITE, A. (2014). "Valuing Derivatives: Funding Value Adjustments and Fair Value". Financial Analysts Journal, 70(3), pp.46-56.

INTERNATIONAL ACCOUNTING STANDARDS BOARD (IASB) (2008). "Discussion Paper: Reducing Complexity in Reporting Financial Instruments". Available at: http://www.asc.gov.sg/Portals/0/attachments/Consultations/dp-

\%20reducing\%20complexity\%20in\%20reporting\%20financial\%20instruments.pdf [last consultation: 25/11/2017]

JOINT WORKING GROUP OF STANDARD SETTERS (JWG) (2000). Draft Standard and Basis for Conclusions: Financial Instruments and Similar Items International Accounting Standards Committee, London. Available at: http://aeca.es/old/faif/ documentos/1_2_preface_draft_standard_final.pdf [last consultation: 28/01/2018]

KEYTON, R. and KEYTON, C. (2016). "Accounting for KVA under IFRS 13". Risk.net. Available at: https://papers.ssrn.com/sol3/papers.cfm?abstract_id $=2620454$ [last consultation: 10/12/2017] 
KHURANA, I.K., and KIM, M-S. (2003). "Relative Value Relevance of Historical Cost vs. Fair Value: Evidence From Bank Holding Companies". Journal of Accounting and Public Policy, 22, pp. 19-42.

KOLEV, K. (2008). "Do investors perceive marking-to-model as marking-to-myth? Early evidence from FAS 157 disclosure". Available at: https://ssrn.com/abstract=1336368 [last consultation: 25/11/2017]

LAGHI, E., PUCCI, S., TUTINO, M. and DI MARCANTONIO M. (2012). "Fair Value Hierarchy in Financial Instruments Disclosure. Is Transparency Well Assessed For Investors? Evidence from Banking Industry". Journal of Governance and Regulation, 1 (4), pp.1-19.

LANDSMAN, W.R. (2007). "Is Fair Value Accounting Information Relevant and Reliable? Evidence from Capital Market Research". Accounting and Business Research Special Issue: International Accounting Policy Forum, pp. 19-30.

LARRÁN, M. and PIÑERO, J.M. (2005). "El Modelo de Ohlson (1995): ¿Hemos Llegado Realmente a Comprenderlo?". Revista de Contabilidad, 8(16), pp. 115-149.

LAURENCE, A., SIRIVIRIYAKUL, S. and SLOAN, R.G. (2016) "Who's the Fairest of Them All? Evidence from Closed-End Funds". The Accounting Review, 91(1), pp. 207-227.

LAUX, C. and Leuz, C. (2009). "The Crisis of Fair Value Accounting: Making Sense of the Recent Debate". Accounting, Organizations and Society, 34, pp. 826-834.

LIANG, L. and RIEDL, E.J. (2014) "The Effect of Fair Value versus Historical Cost Reporting Model on Analyst Forecast Accuracy". The Accounting Review, 89(3), pp. 1151-1177.

LONGSTAFF, F. A. and RAJAN A. (2008). "An Empirical Analysis of the Pricing of Collateralized Debt Obligations". Journal of Finance, 63, pp. 529-563.

MAGLIOLO, J. (1986). "Capital Market Analysis of Reserve Recognition Accounting". Journal of Accounting Research, 24, pp. 69-108.

MAGNAN, M., MENINI, A., and PARBONETTI, A. (2015). "Fair value accounting: information or confusion for financial markets?". Review of Accounting Studies, 20(1), pp. 559-591.

MARRA, A. (2016). "The Pros and Cons of Fair Value Accounting in a Globalized Economy: A Never Ending Debate". Journal of Accounting and Finance, 31(4), pp. 582591.

MATIS, D., DAMIAN, M. I., and BONACI, C. G. (2013). "Fair Value Measurement Disclosures: Particularities in the Context of Listed Companies and European Funding". Annales Universitatis Apulensis: Series Oeconomica, 15(1), pp. 40-53

MENICUCCI, E. and PAOLUCCI, G. (2016). "Fair Value Accounting and the Financial Crisis: a Literature-Based Analysis". Journal of Financial Reporting and Accounting, 14(1), pp. 49-71.

MORALES, J. (2015). "IFRS 13 and the Credit Value Adjustment in Derivatives Valuation (CVA/DVA)". Revista Contable, 29, pp. 24-47.

MORALES, J. (2017). "Fair Value in Financial Instruments Accounting. Analysis from a Historical Perspective". DE COMPUTIS Spanish Journal of Accounting History, 26, pp. 90-154.

NELSON, K. (1996). "Fair Value Accounting for Commercial Banks: An Empirical Analysis of SFAS No.107". The Accounting Review, 71(2), pp. 161-182. 
NEVADO, D. and LÓPEZ, V. R. (2002). "Indicadores del Capital Intelectual: el Caso de Entidades de Crédito". Partida Doble, 132. pp. 58-69.

OHLSON, J.A. (1980). "Financial Ratios and the Probabilistic Prediction of Bankruptcy". Journal of Accounting Research, 18 (1), pp. 109-131.

OHLSON, J.A. (1995). "Earnings, Book Values, and Dividends in Equity Valuation". Contemporary Accounting Research, 11 (2), pp. 661-687.

PARK, M.S., PARK T., and RO, B.T. (1999). "Fair Value Disclosures for Investment Securities and Bank Equity: Evidence from SFAS No. 115". Journal of Accounting, Auditing and Finance, 14(3), pp. 347-370

SAPKAUSKIENE, A., and ORLOVSKIJ, S. (2017). "The usefulness of fair value estimates for financial decision making - a literature review". Zeszyty Teoretyczne Rachunkowosci, 93 (149), pp.163-173.

SHANKILN, S., HUNTER, D. and EHLEN, C. (2011). "A Retrospective View of the IFRS's Conceptual Path and Treatment of Fair Value Measurement in Financial Reporting". Journal of Business \& Economics Research, 9(3), pp. 23-28.

SIMKO, P. (1999). "Financial Instruments Fair Value and Non-Financial Firms". Journal of Accounting, Auditing \& Finance, 14(2), pp. 247-274.

SEC, 2008. "Report and Recommendations Pursuant to Section 133 of the Emergency Economic Stabilization Act of 2008: Study on Mart To-Market Accounting". http://www.sec.gov/news/studies/2008/marktomarket123008.pdf [last consultation: 25/11/2017]

SIEKKINEN, J. (2017). "Board Characteristics and the Value Relevance of Fair Values". Journal of Management \& Governance, 21(2), pp. 435-471

SONG, C. J., THOMAS, W.B. and YI, H. (2010). "Value Relevance of FAS 157 Fair Value Hierarchy Information and the Impact of Corporate Governance Mechanisms". The Accounting Review, 85(4), pp. 1375-1410.

TUA, J. (1990). "Algunas Implicaciones del Paradigma de la Utilidad en la Disciplina Contable". Contaduría Universidad de Antioquía, 16, pp. 16-48.

VYAS, D. (2010). "The Timeless of Accounting Write-Downs by US Financial Institutions During the Financial Crisis 2007-2008". Journal of Accounting Research, 49(3), pp823-860.

WANG, L., PERVAIZ, A. and MAKAR, S. (2005). "The Value-Relevance of Derivative Disclosures by Commercial Banks: A Comprehensive Study of Information Content Under SFAS Nos. 119 and 133". Review of Quantitative Finance and Accounting. 25(4). pp. 413-427.

YAO D., PERCY M., STEWARD J., and HU F. (2016). "Determinants of Discretionary Fair Value Measurements: The Case of Level 3 Assets in the Banking Sector". Accounting and Finance, pp 1-37. 
